\title{
IDENTIFIKASI TINGKAT KUALITAS PELAYANAN JASA PENDIDIKAN DENGANMENGGUNAKAN SERVQUALDI FAKULTAS TEKNIK UNIVERSITAS X
}

\author{
Chalis Fajri Hasibuan, Sutrisno \\ Program Studi Teknik Industri \\ Universitas Medan Area Sumatera Utara \\ chalisfajri@yahoo.co.id
}

\begin{abstract}
Abstrak
Persaingan di dalam dunia pendidikan dewasa ini semakin ketat, khususnya perguruan tinggi, bukan hanya perguruan tinggi dalam negeri saja yang menjadi pesaing tetapi juga perguruan tinggi luar negeri.Minat masyarakat Indonesia semakin tinggi terhadap perguruan tinggi luar negeri yang menawarkan kualitas jasa pendidikan yang lebih baik. Adapun tujuan dalam penelitian ini yaitu Mengukur tingkat kepuasan mahasiswa/i Fakultas Teknik Universitas X terhadap pelayanan jasa yang diberikan oleh Fakultas Teknik Universitas X. Jenis penelitian yang digunakan adalah penelitian deskriptif dengan teknik survey.Metode yang digunakan adalah metode Servqual.Metode servqual digunakan untuk menentukan atribut serta mengukur kesenjangan (gap) antara harapan dengan persepsi konsumen terhadap suatu pelayanan. Hasil penelitian diperoleh gap Dengan nilai terbesar yakni -0.9186 menunjukkan bahwa fasilitas yang diberikan belum sesuai dengan biaya uang kuliah yang dibayarkan oleh mahasiswa sedangkan Tingkat pendidikan Dosen yang mengajar di UMA sudah berpendidikan minimal S2 dengan gap yang bernilai positif sebesar 0.0679 yang mengindekasikan bahwa tingkat harapan yang ada pada mahasiswa lebih rendah dari kinerja yang diberikan oleh Universitas $X$.
\end{abstract}

Kata Kunci : Tingkat Kepuasan, Servqual, Perguruan Tinggi, Mahasiswa, Pelayanan Jasa

\section{PENDAHULUAN}

Jasa/pelayanan merupakan suatu kinerja penampilan, tidak berwujud dan cepat hilang, lebih dapat dirasakan dari pada dimiliki, serta pelanggan lebih dapat berpartisipasi aktif dalam proses mengkomsumsi jasa tersebut. Dalam strategi pemasaran, definisi jasa harus diamati dengan baik, karena pengertiannya sangat berbeda dengan produk berupa barang. Kondisi dan cepat lambatnya pertumbuhan jasa akan sangat bergantung pada penilaian pelanggan terhadap kinerja yang ditawarkan oleh pihak produsen [1]. analisis kepuasan pelanggan di tempat pendidikan sudah dilakukan oleh beberapa peneliti dibeberapa tempat pendidikan bukan hanya di universitas seperti yang dilakukan oleh [2] yang dilakukan di pendidikan bahasa inggris LBPP LIA dengan hasilnya Hasil perhitungan menunjukan bahwa terdapat 20 atribut pelayanan jasa bernilai negatif pada Gap5

Pelayanan yang baik yang diberikan oleh universitas ataupun jurusan kepada mahasiswa akan meningkatkan kepercayaan masyarakat untuk menitipkan anak-anak mereka untuk memperoleh pendidikan yang terbaik dari universitas ataupun jurusan sehingga menambah nilai jual universitas di mata masyarakat [3]. Universitas $X$ merupakan universitas swasta terbesar yang memiliki fasilitas yang memadai yang memiliki fakultas ekonomi, biologi, pertanian, hukum, teknik, psikologi dan ilmu politik dan sosial.Untuk meningkatkan minat mahasiswa baru yang akan memilih universitas $X$ sebagai tempat menuntut ilmu maka diperlukan penilaian kepuasan mahasiswa yang sudah menggunakan jasa Universitas $\mathrm{X}$ dalam mendidik mereka sehingga pihak universitas dapat mengevaluasi jasa pelayanan untuk diperbaiki, dalam penelitian ini yang menjadi objek penelitian adalah fakultas teknik, hal yang mendasari pemilihan fakultas teknik karena fakultas teknik memiliki 5 jurusan dan penggunaan laboratorium yang cukup banyak dibandingkan dengan fakultas lain.

\section{LANDASAN TEORI}

\section{A. Kajian Pustaka}

Penelitian yang dilakukan oleh peneliti tentang analisis kepuasan pelanggan di tempat pendidikan sudah dilakukan oleh beberapa peneliti dibeberapa tempat pendidikan bukan 
hanya di universitas seperti yang dilakukan oleh Nugraha (2015)[4] yang dilakukan di pendidikan bahasa inggris LBPP LIA dengan hasilnya Hasil perhitungan menunjukan bahwa terdapat 20 atribut pelayanan jasa bernilai negatif pada Gap5. Terdapat masingmasing 10 atribut yang ditemukan bernilai negatif pada perhitungan Gap 1 dan Gap 3, yang merupakan penyebab terjadinyaGap5 bernilai negatif.Selain itu terdapat pula 3 atribut yang telah dijanjikan dan dikomunikasikan secara eksternal oleh lembaga, bernilai negatif pada perhitungan Gap4.

Hal yang serupa juga dilakukan oleh Nidhomuzzaman (2011)[5] yang melakukan penelitian terhadap pelayanan jasa di MAN Sidoarjo yang menghasilkan penelitian Dari hasil analisis Servqual terbobot diketahui indikator yang harus ditingkatkan kualitas layanannya adalah kecepat-tanggapan pihak manajemen dengan keluhan siswa-siswi (X3.1) dengan serqual terbobot -0.16007, kecepatan tanggapan karyawan dalam memberikan bantuan yang di minta oleh siswa-siswi (X3.2) dengan serqual terbobot -0.10858 , luas area parkir (X1.5) dengan serqual terbobot -0.10281 , kesesuaian materi pelajaran yang di ajarkan dengan yang di program (X2.2) dengan serqual terbobot -0.08799 , ketepatan waktu belajar mengajar dengan jadwal (X2.1) dengan serqual terbobot -0.08084 , kecepatan tanggapan pengajaran dalam hal pertanyaan kritikan dan keluhan dari siswa-siswi (X3.3) dengan serqual terbobot 0.0748, desain ruang belajar mengajar (X1.2) dengan serqual terbobot -0.05993, kebersihan dan kenyamanan ruangan belajar mengajar dan fasilitasnya (X1.3) dengan serqual terbobot -0.05545 . Penelitian yang dilakukan oleh Baheransyah, (2012) dengan mengidentifikasi kualitas pelayanan jasa pendidikan Sekolah Menengah Atas (XYZ) dengan hasil terdapat 12 atribut pelayanan yang harus diperbaiki dari 32 atribut yang di ujikan sehingga sekolah tersebut sudah lebih dari setengah pelayanan yang sudah sesuai dengan harapan siswa SMS XYZ

Penelitian terhadap jasa pendidikan juga dilakukan di perguruan tinggi seperti yang dilakukan oleh Wulandari, et al (2014)[6] dengan hasil penelitian yang diperoleh Gap tertinggi dari kesenjangan antara tingkat kepentingan dan tingkat kepuasan terdapat pada ketersediaan fasilitas internet. Peneliti lain yang melakukan penilaian kualitas dilakukan oleh Jiwantara, (2013)[7] melakukan penelitian pada balai bahasa yang menghasilkan Penyuluhan Bahasa Indonesia Praktis di Balai Bahasa Provinsi Sulawesi Utara. Setelah itu dihasilkan kualitas pelayanan antara range -0.14 sampai dengan 0.28 yang menunjukkan kualitas pelayanan mendekati ideal dan tingkat kepuasan dengan nilai $88 \%$ menunjukkan bahwa pesuluh puas terhadap kualitas pelayanan jasa. Hal yang sama juga dilakukan oleh Sahyar, (2012)[8] yang meneliti kepuasan pelanggan dalam hal pendidikan pendidikan tinggi dengan hasil yang diperoleh Penelitian ini menyimpulkan bahwa dari 22 atribut kualitas jasa pendidikan diperoleh 19 atribut dalam kategori baik, tiga atribut perlu mendapat prioritas perbaikan yaitu: fasilitas sumber belajar, keandalan penggunaan waktu dalam proses pembelajaran dan kecepatan layanan administrasi. Sumber pemborosan yang dominan adalah waktu tunggu dalam menerima jasa dan produk jasa yang belum memuaskan.

\section{B. Pengertian Jasa}

Jasa/pelayanan merupakan suatu kinerja penampilan, tidak berwujud dan cepat hilang, lebih dapat dirasakan dari pada dimiliki, serta pelanggan lebih dapat berpartisipasi aktif dalam proses mengkomsumsi jasa tersebut. Dalam strategi pemasaran, definisi jasa harus diamati dengan baik, karena pengertiannya sangat berbeda dengan produk berupa barang. Kondisi dan cepat lambatnya pertumbuhan jasa akan sangat bergantung pada penilaian pelanggan terhadap kinerja yang ditawarkan oleh pihak produsen [9] 


\section{Kualitas Pelayanan Jasa}

Menurut Parasuraman (1988)[10] ada lima atribut yang perlu diperhatikan oleh manajemen industri jasa diantaranya yaitu :

1. Keandalan (reliability) adalah kemampuan dari pihak pemberi jasa dalam memberikan apa yang dijanjikan kepada penerima jasa (pelanggan) secara akurat.

2. Jaminan (assurance) berkaitan dengan pengetahuan, kesopanan, dan kemampuan dari pekerja (pemberi jasa) untuk membangkitkan rasa kepercayaan dan keyakinan dari penerima jasa (pelanggan) atas jasa yang diterima itu.

3. Bukti langsung (tangibles) berkaitan dengan fasilitas-fasilitas fisik, peralatan, dan penampilan dari personel pemberi jasa.

4. Empati (empathy) adalah perhatian dan kepedulian pemberi jasa kepada pelanggan.

5. Daya tanggap (responsiveness) berkaitan dengan tanggung jawab dan keinginan untuk memberikan jasa yang prima serta membantu pelanggan apabila menghadapi masalah berkaitan dengan jasa yang diberikan oleh pemberi jasa.

\section{METODE PENELITIAN}

\section{A. Tempat dan Waktu Penelitian}

Penelitian dilakukan di Fakultas Teknik Universitas X dengan 5 jurusan yaitu teknik elektro, teknik mesin, teknik sipil, teknik industri dan arsitektur. Waktu penelitian selama 10 bulan.

\section{B. Jenis Penelitian}

Jenis penelitian yang digunakan adalah penelitian deskriptif dengan teknik survey.Penelitian deskriptif bertujuan untuk mendeskripsikan secara sistematik, faktual dan akurat tentang fakta-fakta dan sifat-sifat suatu objek atau populasi tertentu.Teknik survey dilakukan untuk memperoleh fakta-fakta dari gejala yang ada dan mencari keterangan secara faktual untuk mendapatkan kebenaran. Dengan menggunakan 8 standar nasional perguruan tinggi.

Dari delapan standar pendidikan yang disebutkan, kemudian akan dikelompokkan sesuai dengan lima dimensi kualitas pelayanan jasa yaitu [11]

1. Tangible

2. Reliability

3. Responsiveness

4. Assurance

5. Empathy

\section{Uji Validitas Dan Reliabilitas}

Pengujian ini bertujuan untuk mengukur keampuhan dari kuesioner yang telah disusun.Pengujian validitas dilakukan dengan membandingkan harga korelasi perhitungan setiap butir pertanyaan dengan tabel angka kritik korelasi product moment.

$$
r=\frac{n\left(\sum X Y\right)-\left(\sum X \sum Y\right)}{\sqrt{\left[\left(n \sum X^{2}-\left(\sum X\right)^{2}\right)\left[n \sum Y^{2-}\left(\sum X\right)^{2}\right]\right.}}
$$

Sedangkan pengujian reliabilitas kuesioner dilakukan dengan menggunakan harga koefisien Alpha Cronbach

$$
r=\left[\frac{k}{k-1}\right]\left[1-\frac{\sum \sigma^{2} b}{\sigma^{2} t}\right]
$$




\section{Blok Diagram Prosedur Penelitian}

Prosedur penelitian adalah tahapan-tahapan dalam melaksanakan suatu penelitian. Adapun prosedur dalam penelitian ini dapat dilihat pada blok diagram

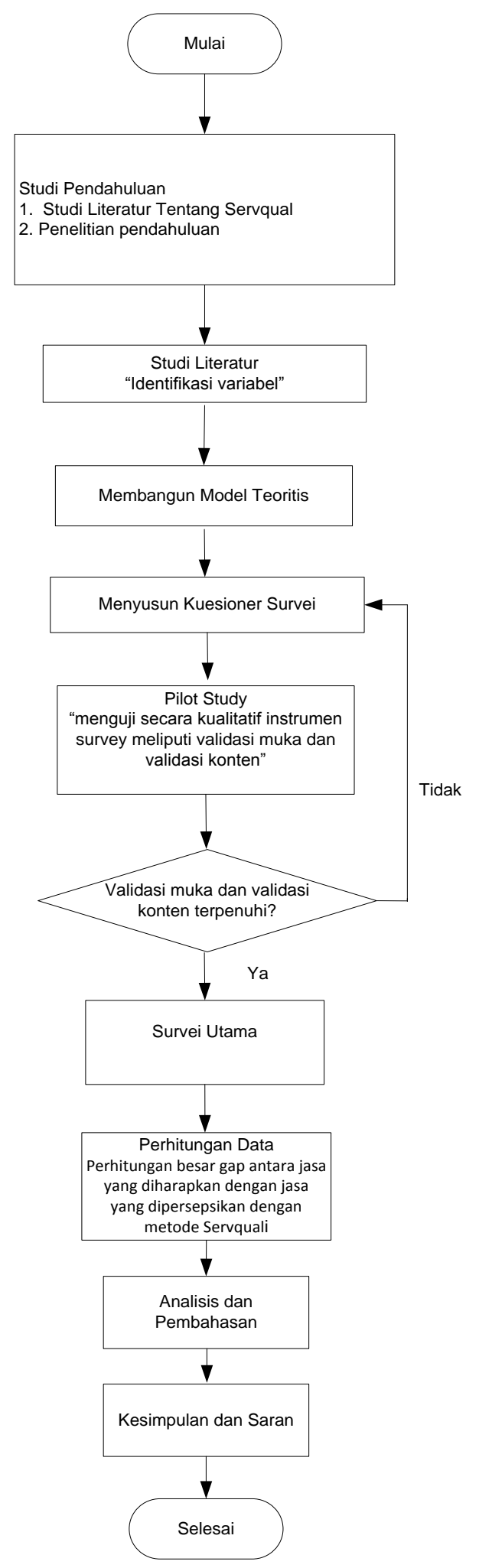

Gambar 1. Blok Diagram Prosedur Penelitian 


\section{HASIL DAN PEMBAHASAN}

\section{A. Hasil}

Dari hasil pengolahan data kuesioner mahasiswa untuk kinerja dan harapan terhadap kualitas pelayanan jasa pendidikan Fakultas Teknik Universitas X, diperoleh gambaran adanya gap antara kinerja dan harapan mahasiswa.Gap ini menunjukkan bahwa pelayanan yang diberikan Fakultas Teknik Universitas X pada suatu variabel kualitas pelayanan tidak sesuai dengan harapan mahasiswa.Untuk mengetahui gap ini, digunakan nilai rata-rata kinerja dan harapan dari setiap variabel kualitas pelayanan tersebut.

Untuk variabel 1, nilai gap-nya sebesar :

Gap 1 = rata-rata nilai kinerja 1 - rata-rata nilai harapan 1

Gap $1=2,8597-3,3846=-0,5249$

Tabel 1. Nilai Gap Tingkat Kepuasan (Kinerja) dan Tingkat Kebutuhan (Harapan) Mahasiswa

\begin{tabular}{|c|c|c|c|c|c|}
\hline Rangking & NO & Variabel & $\begin{array}{c}\text { Mean } \\
\text { Kinerja }\end{array}$ & $\begin{array}{c}\text { Mean } \\
\text { Harapan }\end{array}$ & GAP \\
\hline 1 & 11 & $\begin{array}{l}\text { Tingkat pendidikan Dosen yang mengajar di UMA sudah } \\
\text { berpendidikan minimal S2 }\end{array}$ & 3.3167 & 3.2489 & 0.0679 \\
\hline 2 & 5 & Bagaimana menurut anda Kondisi fisik kantin & 2.9955 & 3.0814 & -0.0860 \\
\hline 3 & 23 & $\begin{array}{l}\text { Menurut anda bagaimana Penilaian yang objektif (terbuka) } \\
\text { terhadap setiap mahasiswa dilakukan oleh dosen pengampu } \\
\text { mata kuliah atau laboratorium }\end{array}$ & 2.9864 & 3.0860 & -0.0995 \\
\hline 4 & 16 & Ketepatan waktu dosen dalam mengajar & 3.2941 & 3.4027 & -0.1086 \\
\hline 5 & 20 & $\begin{array}{l}\text { Menurut anda bagaimana Sikap personal kampus dalam } \\
\text { melayani kebutuhan mahasiswa }\end{array}$ & 2.9910 & 3.1131 & -0.1222 \\
\hline 6 & 6 & $\begin{array}{l}\text { Bagaimana menurut anda Fasilitas ruang kuliah yang } \\
\text { tersedia saat ini (white board, proyektor, LCD, dan } \\
\text { sebagainya) }\end{array}$ & 3.2172 & 3.3756 & -0.1584 \\
\hline 7 & 4 & Bagaimana menurut anda Kondisi fisik toilet & 2.6335 & 2.8009 & -0.1674 \\
\hline 8 & 19 & Tingkat Angka persentase kelulusan yang tinggi & 2.9502 & 3.1448 & -0.1946 \\
\hline 9 & 8 & $\begin{array}{l}\text { Bagaimana menurut anda Penampilan (cara berpakaian) } \\
\text { personal kampus (dosen, staf pegawai, dan sebagainya) }\end{array}$ & 3.6787 & 3.9005 & -0.2217 \\
\hline 10 & 7 & $\begin{array}{l}\text { Bagaimana menurut anda Fasilitas/ peralatan pendukung } \\
\text { seperti laboratorium saat ini }\end{array}$ & 2.9050 & 3.1403 & -0.2353 \\
\hline 11 & 13 & $\begin{array}{l}\text { Pemakaian faslilitas pembantu dalam proses belajar } \\
\text { mengajar (LCD, dan sebagainya) dapat dipergunakan } \\
\text { sesuai dengan kegunaannya }\end{array}$ & 3.2262 & 3.4661 & -0.2398 \\
\hline 12 & 24 & $\begin{array}{l}\text { Pemberian beasiswa bagi mahasiswa berprestasi dan } \\
\text { kurang mampu }\end{array}$ & 2.4163 & 3.3348 & -0.2443 \\
\hline 13 & 17 & $\begin{array}{l}\text { Ketepatan waktu dosen dalam mengajar kuliah } \\
\text { pengganti }\end{array}$ & 3.3710 & 3.6290 & -0.2579 \\
\hline 14 & 14 & $\begin{array}{l}\text { Kesigapan personal perguruan tinggi (dosen, staf } \\
\text { pegawai, dan sebagainya) dalam menanggapi kebutuhan } \\
\text { dan keluhan mahasiswa }\end{array}$ & 2.7059 & 3.0452 & -0.3394 \\
\hline 15 & 9 & $\begin{array}{l}\text { Bagimana Kurikulum yang terdapat di Universitas X } \\
\text { apakah sudah sesuai dengan standar nasional menurut } \\
\text { anda }\end{array}$ & 3.4434 & 3.8145 & -0.3710 \\
\hline 16 & 3 & Bagaimana menurut anda Kondisi fisik perpustakaan & 3.0452 & 3.4706 & -0.4253 \\
\hline 17 & 2 & Bagimana menurut anda Kondisi fisik, laboratorium & 2.5973 & 3.0271 & -0.4299 \\
\hline 18 & 25 & $\begin{array}{l}\text { Bagaimana Kemampuan dosen dalam memotivasi } \\
\text { mahasiswa }\end{array}$ & 3.4027 & 3.8371 & -0.4344 \\
\hline 19 & 18 & $\begin{array}{l}\text { Kemampuan dosen dalam menciptakan suasana kelas } \\
\text { yang kondusif }\end{array}$ & 3.1810 & 3.6290 & -0.4480 \\
\hline 20 & 10 & $\begin{array}{l}\text { Bagaimana menurut anda Kemampuan dosen dalam } \\
\text { menyampaikan materi di dalam kelas }\end{array}$ & 3.3937 & 3.8643 & -0.4706 \\
\hline 21 & 1 & Bagaimana menurut anda Kondisi fisik ruang kuliah, & 2.8597 & 3.3846 & -0.5249 \\
\hline 22 & 21 & $\begin{array}{l}\text { Kemampuan lulusan untuk mendapat pekerjaan atau } \\
\text { melanjut ke jenjang Strata } 2 \text { (S2) }\end{array}$ & 2.8824 & 3.4977 & -0.6154 \\
\hline
\end{tabular}




\begin{tabular}{|c|c|c|c|c|c|}
\hline 23 & 15 & $\begin{array}{l}\text { Ketepatan personal kampus dalam menganalisa } \\
\text { kebutuhan mahasiswa }\end{array}$ & 2.7783 & 3.4661 & -0.6878 \\
\hline 24 & 22 & $\begin{array}{l}\text { Menurut anda bagaimana Kemudahan dalam urusan } \\
\text { birokrasi }\end{array}$ & 2.4480 & 3.3213 & -0.8733 \\
\hline 25 & 12 & $\begin{array}{l}\text { Kesesuaian fasilitas dengan biaya uang kuliah di } \\
\text { Universitas X }\end{array}$ & 2.4163 & 3.3348 & -0.9186 \\
\hline
\end{tabular}

Sumber: Hasil Pengolahan Data

\section{B. Analisis Servqual}

Hasil pengolahan data menunjukkan gambaran mengenai kepuasan dan kebutuhan mahasiswa terhadap kualitas Fakultas Teknik Universitas X. Dan juga dapat diketahui kesenjangan (gap) antara pelayanan yang telah diberikan pihak perguruan tinggi dengan persepsi pelayanan yang diterima oleh mahasiswa. Pelayanan dikatakan sudah memenuhi keinginan pelanggan jika gap bernilai positif, dan belum memenuhi keinginan pelanggan jika gap bernilai negative. Nilai-nilai gap secara keseluruhan masih bernilai negatif, yang berarti bahwa secara keseluruhan variabel pelayanan belum dapat memenuhi harapan mahasiswa dan untuk itu, masih diperlukan tindakan perbaikan dari pihak manajemen untuk dapat memenuhi kepuasan konsumen, walaupun untuk satu variable sudah bernilai positif pada bagian tingkat pendidikan dosen yang mengajar lebih tinggi kinerja dari pada harapan mahasiswa yang berarti mahasiswa merasa sangat puas dengan tingkat pendidikan dosen yang mengajar, sedangkan gap negativ terbesar diperoleh pada variable Kesesuaian fasilitas dengan biaya uang kuliah di Universitas X dengan nilai gap -0.9186 menunjukkan bahwa fasilitas yang diberikan belum sesuai dengan biaya uang kuliah yang dibayarkan oleh mahasiswa.

\section{KESIMPULAN DAN SARAN}

\section{A. Kesimpulan}

Berdasarkan hasil pengolahan data dan analisis yang telah dilakukan dapat diambil beberapa kesimpulan sebagai berikut:

1. Variabel pelayanan yang digunakan mahasiswa dalam menilai kualitas pelayanan Fakultas Teknik Universitas X adalah sebanyak 25 atribut, yang digolongkan dalam lima dimensi servqual, yang meliputi kondisi fisik ruangan kampus, fasilitas ruang kuliah, kurikulum yang sesuai dengan standar nasional, kemampuan dosen dalam menyampaikan materi, kesigapan personal perguruan tinggi (dosen, staf pegawai, dan sebagainya) dalam menanggapi kebutuhan dan keluhan mahasiswa, ketepatan personal kampus dalam menganalisa kebutuhan mahasiswa, angka persentase kelulusan yang tinggi, sikap personal kampus dalam melayani kebutuhan mahasiswa, penilaian yang objektif (terbuka) terhadap setiap mahasiswa, pemberian beasiswa bagi mahasiswa berprestasi dan kurang mampu.

2. Kualitas pelayanan jasa di Fakultas Teknik Universitas $\mathrm{X}$ belum sepenuhnya memuaskan mahasiswa karena hampir seluruh variabel pelayanan yang dinilai memiliki nilai gap yang negatif. Dengan nilai gap terbesar yakni -0.9186 menunjukkan bahwa fasilitas yang diberikan belum sesuai dengan biaya uang kuliah yang dibayarkan oleh mahasiswa sehingga perlu dilakukan perbaikan terhadap fasilitas utama dan penunjang yang dapat dirasakan oleh mahasiswa teknik untuk memperlancar kegiatan belajar dan mengajar.

3. Kualitas pelayanan pada variable Tingkat pendidikan Dosen yang mengajar di UMA sudah berpendidikan minimal S2 dengan gap yang bernilai positif sebesar 0.0679 yang mengindekasikan bahwa tingkat harapan yang ada pada mahasiswa lebih rendah dari kinerja yang diberikan oleh Universitas X 


\section{B. Saran}

Setelah melakukan penelitian tugas sarjana ini, adapun saran yang dapat diajukan adalah :

1. Pihak manajemen dapat memfokuskan perhatiannya pada perbaikan variabel pelayanan yang belum dapat memenuhi kepuasan para pelanggannya sesuai dengan urutan prioritas perbaikan.

2. Pihak manajemen dapat secara berkala dan berkesinambungan melakukan evaluasi pelayanan jasa pendidikan yang diberikan kepada mahasiswa sehingga dapat diketahui tingkatan pelayanan serta perencanaan perbaikan secara mendetail.

3. Pihak manajemen perguruan tinggi sebaiknya lebih memperhatikan fasilitas peralatan yang sebanding dengan pembiayaan uang kuliah yang dibebankan kepada mahasiswa seperti kelengkapan peralatan komputer (earphone, microphon, dan software pendukung), jaringan internet yang baik, dan keamanan fasilitas parkiran.

\section{Daftar Pustaka}

[1] Apriani, B, 2013. Analisis Kualitas Pelayanan Jasa Pendidikan DenganMenggunakan Quality Function DeploymentDi Jurusan Akuntansi Xyz, eJurnal Teknik Industri FT USU Vol 3, No. 1, September 2013 pp. 47-51

[2] Baheramsyah, 2012. Identifikasi Dan Evaluasi Tingkat Kualitas Pelayanan Jasa Pendidikan Sekolah Menengah Atas (XYZ), Skripsi Universitas Indonesia, Jakarta

[3] Chen, KeeKuo., Chang, ChingTer., Lai, ChengSheng. (2009) 'Service quality gaps of business customers in the shipping industry', TransportationResearch Part E 45, 222237

[4] Nugraha, L., 2015. Usulan Peningkatan Kualitas Pelayanan JasaPendidikan Bahasa Inggris MenggunakanMetode Service Quality(Servqual)Di Lbpp Lia MartadinataKota Bandung. Jurnal Online Institut Teknologi Nasional, No.01 | Vol.03

[5] Nidhomuzzaman, 2011.Analisis Kualitas Layanan Jasa Pendidikan Dengan Metode Servqual Dan AnalyticalHierarchy Process (Ahp)Di Madrasah Aliyah Negeri (Man) Sidoarjo, Skripsi Universitas Pembangunan Nasional "Veteran". Jawa Timur

[6] Wulandari, 2014. Strategi Peningkatan Kualitas Layanan Pendidikan Menggunakan Integrasi Metode Fuzzy Servqual Dan QFD(Studi Kasus : Program Studi S1 Sistem Informasi STIKOM SURABAYA), Journal ITS,Surabaya

[7] Jiwantara, 2013.Penerapan Metode Servqual Untuk Evaluasi Dan Perbaikan Kualitas Pelayanan Pada KegiatanPenyuluhan Bahasa Indonesia PraktisDi Balai Bahasa Provinsi Sulawesi Utara, Universitas Sam Ratulangi Manado.

[8] Sahyar, 2012. Analisis Kualitas Jasa Pogram Studi Pendidikan Tinggi DenganMetode Servqual (Service Quality) Dan Six Sigma, Pekbis Jurnal, Vol.4, No.3, November 2012: 141-151

[9] Tjiptono, F., Diana, A., 2005, Total Quality Management, Edisi Revisi, Penerbit Andi, Yogyakarta.

[10] Parasuraman, A., Zeithaml, V.A., Dan Berry, L.L. (1988). 'Theory Of The Gaps Model In Service Marketing', The Marketing Association Of Australia And NewZealand .

[11] Valerie A Zeithaml,dkk. Delivering Quality. Free Press. New York. 1990 
